\title{
Observations on Variations in the Flowers of Stachys sylvatica, Linn.
}

\author{
BY \\ E. M. CUTTING, M.A., F.L.S., \\ Assistant, University College, University of London.
}

\section{With five Figures in the Text.}

FOR some years the writer has observed, in the Hedge Woundwort, 1 the presence of flowers varying, more or less markedly, from the normal. At first notes and sketches only were made of typical variants and also of the more striking ones; but in I9I9, for a short time, in the early autumn, a preliminary statistical study of these forms was begun. It should be stated that the variations recorded have been found on sandy, chalky, and loamy soils, in different localities (e.g. at Haslemere in Surrey, Shoreham in Kent, and in the neighbourhood of High Wycombe in Buckinghamshire) and at different times of the year, namely, from June to October. The observations so far made, however, do not enable one to judge how far the soil and the time of year influence either the percentage or the nature of the variations.

\section{Table I. Series A. Haslemere. August, igi6.}

$\begin{array}{lccccccc} & \text { K. } & \text { C. } & \text { A. } & \text { G. } & \text { N. } & \begin{array}{c}\text { Remarks. } \\ \text { M.F. }\end{array} & \text { Fig. I. } \\ \text { I. f. } & 8 & 2+3 & 6 & \ldots & \text { Io } & \text { M.F., I N.F. on each side } & a \\ \text { 2. f. } & 5 & 3+3 & 5 & 2 & \ldots & \text { M.F., I N.F. on each side } & e \\ \text { 3. f. } & 5 & 3+3 & 5 & 3 & \ldots & \ldots & \ldots \\ \text { 4. } & 5 & 2+3 & 5 & 3 & \ldots & \ldots & \ldots \\ 5 . & 5 & 2+3 & 4 & 2 & \ldots & \text { M.F. } & \ldots \\ \text { 6. } & 5 & \text { I }+3 & 5 & 2 & 4 & \text { M.F. } & \ldots \\ 7 . & 4 & 2+3 & 5 & 3 & 5 & \text { M.F. } & \ldots \\ \text { 8. } & 5 & 2+3 & 5 & 2 & 4 & \ldots & \ldots \\ 9 . & 5 & 2+3 & 4 & 2 & \ldots & \ldots & \ldots \\ \text { IO. } & 5 & 2+3 & 5 & 2 & \ldots & \text { M.F. } & \\ \text { II. } & 5 & 2+3 & 4 & 2 & 4 & \end{array}$

The first series (see Table I) that was observed was collected at Haslemere in August, I9I6. The tendencies here shown were towards an increased number of parts leading up to cases of fasciation (Fig. I, $a, d$, and e). A large number of flowers were found in which the upper lip of the corolla was larger and wider than usual and a smaller number in which it

[Annals of Botany, Vol. XXXV. No. CXXXIX. July, 1921.] 
was distinctly notched at the apex (Fig. I, $f$ ). Of these, unfortunately, no record was made. There were other forms, however, which were provided with five stamens instead of the usual four; some of these showed three stigmas, two had five 'nutlets' (Fig. I, $c$ ) recorded for them (records were seldom made of the number of nutlets), most of them had notched upper lips to the corolla, and two of them had two upper lips and in each case one of these lips was notched. These two cases should probably be regarded as incipient fasciations. One of the specimens was remarkable in that it possessed only four sepals, while the other members of all the other whorls were increased (Table I, 7). In the other cases an increase
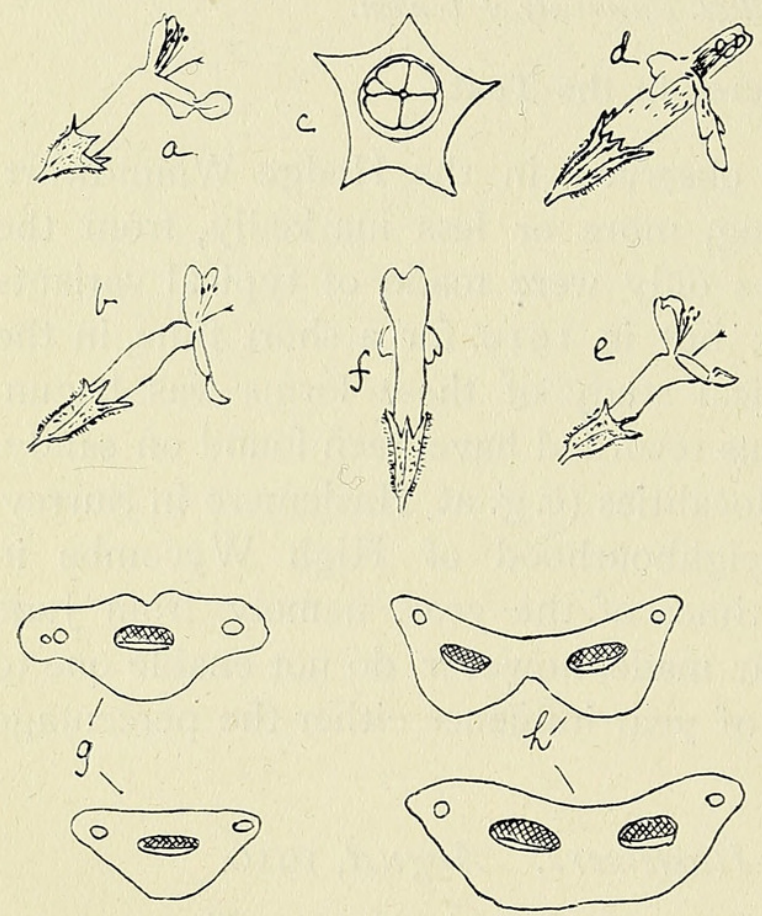

FIg. I. (See Table I.) Semidiagrammatic. $a, b, d, e$, fasciated flowers; $f$, bifurcated upper lip; $c$, five-lobed ovary seen from above; $g$, sections through normal petiole; $h$, sections through abnormal petiole. [Haslemere, Surrey, i 9I6.]
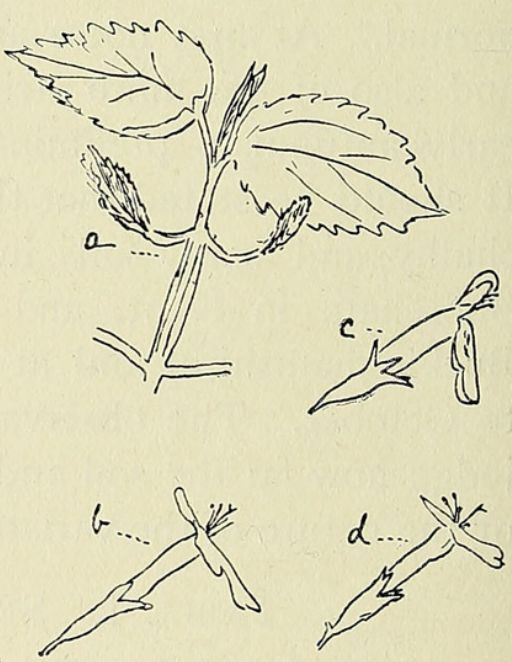

FIG. 2. (See Table II.) $a$, two shoots partly fused to main stem. For description see text and table. [Downley, near High Wycombe, Bucks., I9I 7 .]

in the number of members of any one whorl was usually accompanied by an increase in some other whorl. The undoubted fasciation referred to had eight members to its calyx, two upper corolla lips both bifurcated, six stamens, and ten nutlets (the styles had fallen off). This was a middle flower of a side inflorescence (as indeed all the flowers in this series were in the cases in which a record had been made of the definite position), and the leaf-stalk to the auxiliary leaf of this inflorescence also showed signs of 'forking'; the leaf itself had not been preserved, but if it had shown any peculiar feature it probably would have been. The vascular structure of this petiole is shown in Fig. I, $h$, and may be compared with that of the normal petiole of Fig. I, $g$. 
The next series (see Table II) was collected on the chalk near High Wycombe, late in September and early in October, I9I7. There is only one record of an abnormal side flower. Its formula gives an idea of its nature: $\mathrm{K}_{4}, \mathrm{C}_{1}+4, \mathrm{~A}_{2}, \mathrm{G}(2)$. A similar flower has this formula in my notes $-\mathrm{K}_{3}, \mathrm{C}_{2}+3, \mathrm{~A}_{2}, \mathrm{G}(2)$, but it is not recorded whether it is a side or a middle flower. All the others were middle flowers. Of these, two showed five stamens, in one case with a forked upper lip (Fig. 2, c), and in the other with an upper lip resembling a side lobe of the lower lip; another two showed upper lips similar to the corolla; in one of these there were four sepals and in the other six.

Table II. Series B. Downley. September-October, 1917.

\begin{tabular}{|c|c|c|c|c|c|c|c|}
\hline & $\mathrm{K}$. & C. & A. & G. & N. & Remarks. & Fig. 2. \\
\hline$I^{x} f_{0}$ & IO & $\begin{array}{l}1+3 \\
I+3\end{array}$ & 7 or 8 & $2+3$ & .. & M.F., I N.S.F. & $\ldots$ \\
\hline 2. $f$. & IO & I & $\dddot{8}$ & $2+2$ & $\ldots$ & M.F., I N.S.F. & \\
\hline & $\cdots$ & $\left\{\begin{array}{l}\mathrm{I}+3 \\
\mathrm{I} ?\end{array}\right.$ & $\cdots$ & $\cdots$ & $\cdots$ & $\ldots$ & $\cdots$ \\
\hline $3 .^{x} \mathrm{f}$. & I0 & the rest & issing & $\begin{array}{l}\cdots \\
\cdots\end{array}$ & $\begin{array}{l}\cdots \\
\cdots\end{array}$ & M.F., I N.S.F. & $\cdots$ \\
\hline 4. & 5 & $2+3$ & 5 & 2 & $\ldots$ & M.F. & c \\
\hline 5. & 5 & I s.p. +3 & 5 & 2 & $\ldots$ & M.F. & \\
\hline 6 . & 6 & I s.p. +3 & 4 & 2 & $\ldots$ & M.F. & $d$ \\
\hline 7 . & 4 & I s.p. +3 & 4 & 2 & $\cdots$ & M.F. & $b$ \\
\hline 8. & 4 & $I+4$ & 2 & 2 & $\ldots$ & S.F. & $\ldots$ \\
\hline 9. & 3 & $2+3$ & 2 & 2 & $\ldots$ & $\ldots$ & $\ldots$ \\
\hline
\end{tabular}

The other variants recorded were fusions occurring in opposite halfverticillasters between a middle flower and a side flower; one of these free side flowers was normal, the other was unopened but possibly normal, with five sepals. On the side with the opened flower, only ten sepals were shown, the rest of the flower having fallen off. On the other side the following formula expresses the state of affairs :

$$
\mathrm{K} \text { ro, } \mathrm{C} \mathrm{I}+3, \text { A } 7 \text { or } 8 \quad \mathrm{G}(2)+\stackrel{?}{(3)}
$$

Under $\mathrm{C}$ the first series of figures expresses the condition of the upper lip and the second series (after the + ) that of the lower lip; e. g. here there are two lower lips with three lobes to each. There was another fusion in which there seemed to be three upper lips (not adjoining) with three groups of stamens; this was slightly injured, however, and will not be further considered. The interesting forms in this series were those in which the upper lip resembled the side lobe of the lower lip (Fig. 2, $b$ and $d$ ), for these must be regarded as transitional to the peloric and semi-peloric forms which have been found on chalk in July and two of which have been noticed, in September, I9I9, on plants growing on a loam. These will be described below. There was a tendency to reduction in the forms 
mentioned above and also in the forms with two stamens. The fused forms are interesting in that they were found in opposite side inflorescences, a distribution that is very common, as was shown by observations made in I919, and one that probably points to similar external factors acting at the same time in the growth of the side inflorescence, bringing about a similar condition. (Fig. 2, $a$, shows an abnormality similar to that described by Muth in Salvia pratensis (28).) Variants were seen both at Haslemere in I9I 7 and near High Wycombe in the autumn of I9I 8, but no records were kept of them.

Table III. Series C. Shoreham (Kent). Fuly, I9I9.

\begin{tabular}{|c|c|c|c|c|c|c|c|}
\hline & K. & C. & A. & G. & N. & Remarks. & Fig. 3 . \\
\hline$I^{x}{ }^{f}$. & 9 & $\left\{\begin{array}{l}\mathrm{I}+3 \\
\mathrm{I}+3\end{array}\right.$ & 7 or 8 & $2 ?$ & $\cdots$ & & \\
\hline $20^{x} \mathrm{f}$. & $\dddot{8}$ & $\left\{\begin{array}{l}\mathrm{I}+3 \\
\mathrm{I}+3\end{array}\right.$ & $\dddot{8}$ & $\begin{array}{c}\ldots \\
2+2 \\
\ldots\end{array}$ & $\begin{array}{l}\cdots \\
\cdots \\
\ldots\end{array}$ & M.F. & $\dddot{k} "$ \\
\hline 3. f. & 10 & $\left\{\begin{array}{l}1+3 \\
\end{array}\right.$ & 4 & $\ddot{2}$ & $\cdots$ & M.F.? & $k^{\prime \prime \prime}$ \\
\hline 4. & $\cdots$ & $\begin{array}{r}\mathbf{I}+3 \\
2+3\end{array}$ & $\begin{array}{c}4 \\
2+2+I\end{array}$ & 2 & $\ldots$ & M.F. & $\ldots$ \\
\hline 5. & 5 & $1+2$ & 3 & $\frac{\cdots}{2}$ & $\begin{array}{l}4 \\
\ldots\end{array}$ & S.F. & $\begin{array}{l}\cdots \\
\cdots\end{array}$ \\
\hline 6. & 4 & $I+2$ & 3 & 2 & $\ldots$ & S.F. & $e$ \\
\hline 7. & 5 & $I+I$ & 2 & 2 & $\ldots$ & & $f$ \\
\hline 8. & 4 & $I+3$ s.p. & 4 & 2 & $\ldots$ & S.F. & $\ldots$ \\
\hline $90^{*}$ & 4 & 5 & 5 & 2 & $\cdots$ & & $\ldots$ \\
\hline $\begin{array}{l}\text { I0.* } \\
\text { II.* }\end{array}$ & 5 & $\mathrm{I}+3$ & 4 & 3 & $\cdots$ & M.F. & $a$ \\
\hline I 2 . & $\begin{array}{l}0 \\
5\end{array}$ & $\begin{array}{l}6 \\
5\end{array}$ & $\begin{array}{l}4 \\
4\end{array}$ & $\begin{array}{l}2 \\
2\end{array}$ & $\begin{array}{l}\cdots \\
\cdots\end{array}$ & M.F. & c \\
\hline I $3 *^{*}$ & 5 & $I+3$ & 5 & 2 & $\ldots$ & M.F. & $d$ \\
\hline $14 .^{*}$ & 4 & 4 & 4 & 2 & $\ldots$ & M.F. & $b$ \\
\hline 15. & 5 & $\mathrm{I}+3$ & 4 & 2 & $\ldots$ & S.F., a.i., s.e. & $g$ \\
\hline
\end{tabular}

In the middle of July, I919, at Shoreham (Kent) (see Table III), six peloric and semi-peloric forms were found; four of these are known to be middle flowers of the lowest stalked side inflorescence and the others are thought to have been middle flowers of side verticillasters. The symmetry was usually destroyed either numerically or, as in two cases, by the presence of an upright upper lip (Fig. 3, $a$ ). In one of these cases a small flower was found posterior to the semi-peloric form (Fig. 3, $a$ ), and in the autumn of the same year, near High Wycombe, a similar tendency to form a trichasium was indicated in the case of the two semi-peloric forms then found, and also in a form with a completely divided upper lip placed in a line with the lower lip. There were three 'fused ' flowers (Fig. $3, k^{\prime}, k^{\prime}$, and $k^{\prime \prime \prime}$ ), which should be regarded as fusions between a middle and a side flower of a half-verticillaster (as indicated either by a difference in size of flowers or by one being open and the other closed), no undoubted case of fasciation being found. Fused flowers, similar to those here described, are sometimes met with normally, e.g. in certain species of the genera Lonicera (2) and Eucalyptus (49). In one of the reductions only the side petals of the lower lip were present (Fig. $3, e$ ); and in another only one lobe, like a side 
lobe, was present (Fig. 3, f). These specimens resembled two of the semi-peloric forms mentioned above, and three of the four were recorded as side flowers; the one with no record against it was probably a side flower also. There was one flower, a middle one, of a stalked side inflorescence which was pseudo-terminal owing to the destruction of the adjoining side inflorescence and of the main axis. The flower developed in an almost symmetrical manner and had an increased number of parts (Fig. 3,c). The remaining variant (Fig. $3, g$ ) had its upper lip in line with the lower lip. The style was in line with the corolla tube, and the stamens, four in number, did not show above the tube. Flowers like this one were comparatively common in the autumn.

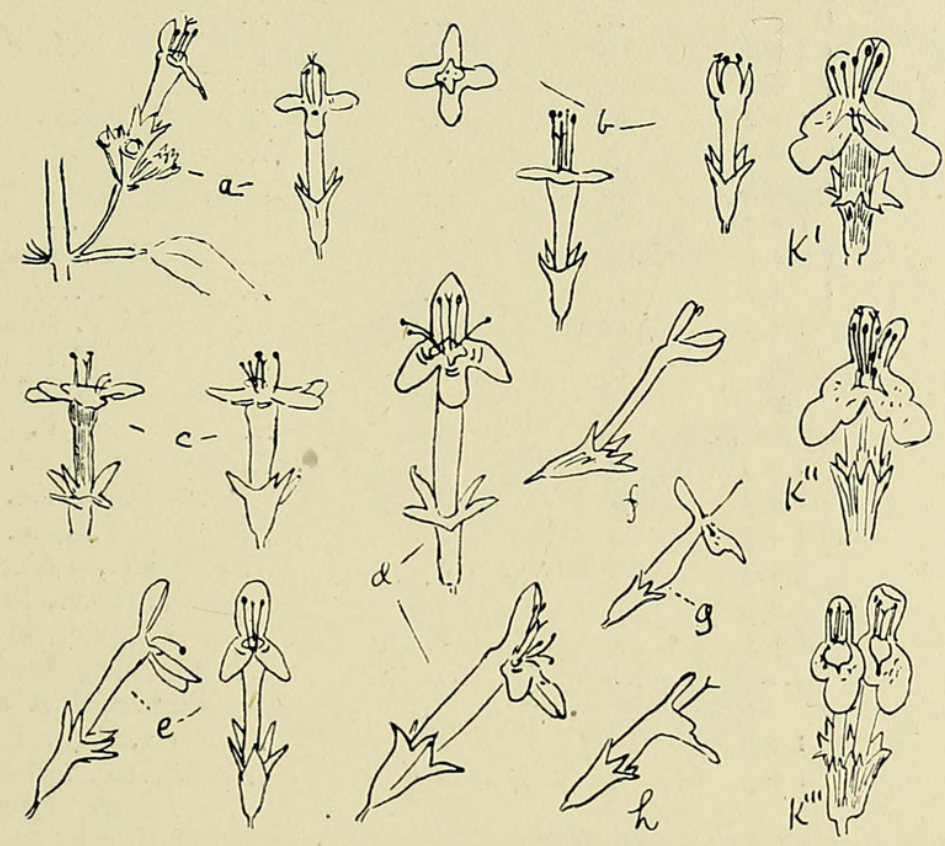

FIG. 3. For description see Table III and text. [Shoreham, Kent, I9i9.]

In the middle of September of I9I9 (see Table IV), on loamy soils near West Wycombe, only two symmetrical (peloric) flowers were found, a few fused flowers, some with the upper lip haif fused with the right or left side petal of the lower lip, a comparatively large number of the type of flower described last in the preceding paragraph, i. e. small flowers with stamens never growing beyond the tube (Fig. $4, d, c$ ), and some of these with shortened styles as well; an examination of these flowers preserved in alcohol showed either no signs of pollen grains or small, shrivelled, and probably abortive ones. An examination with a hand-lens in the field had suggested already that many of these anthers were aborted. The ovaries seemingly were not well developed, but I was unable to make out whether they were abortive as well. The evidence available seems to show that there was a tendency towards the development of gynomonoecism. The 
styles and stigmas were well developed except in a few forms in which the style reached only to the mouth of the tube.

TABLE IV. SERIES D. Naphill (near High Wycombe). September, I9I9.

\begin{tabular}{|c|c|c|c|c|c|c|c|c|}
\hline & K. & C. & A. & G. & & N. & Remarks. & Fig. 4 . \\
\hline I. $f_{0}$ & 8 & 7 & 7 & $2+2$ & & $4+4$ & $\ldots$ & $\ldots$ \\
\hline \multirow[t]{2}{*}{ 2. $f}$. & 9 & $\{I+3$ & 3 & 2 & & $\ldots$ & $\ldots$ & $\ldots$ \\
\hline & $\cdots$ & $\mathrm{I}+3$ & 3 & 2 & & $\cdots$ & $\cdots$ & $k$ \\
\hline 3. f. & $\begin{array}{c}9 \\
\ldots\end{array}$ & \multicolumn{3}{|c|}{$\begin{array}{l}1+3 \\
\text { Unopened side flower }\end{array}$} & & $\ldots$ & $\cdots$ & $\dddot{k}$ \\
\hline 4 . & 5 & $2+3$ & 4 & 2 & & $\ldots$ & M.F. & $g$ \\
\hline 5. & 7 or $6+1$ & $1+3$ & 4 & 3 or $2+1$ & & $\ldots$ & M.F. & $h$ \\
\hline 6. & 5 & $2+3$ & 4 & 2 & & $\ldots$ & $\cdots$ & $\ldots$ \\
\hline 7. & 5 & $2+3$ & 4 & 2 & & $\cdots$ & M.F. & $b$ \\
\hline 8. & 5 & $\left\{\begin{array}{r}I+I \\
+2\end{array}\right.$ & $2 ?$ & 2 & & $\cdots$ & $\ldots$ & $\cdots$ \\
\hline 9 . & $\dddot{5}$ & $1+1$ & $\ddot{3}$ & $\dddot{2}$ & & $\ldots$ & S.F. & \\
\hline & $\cdots$ & $1+2$ & & & & & & \\
\hline $\begin{array}{l}\text { IO. } \\
\text { II. }\end{array}$ & 4 & $I+2$ & $3 ?$ & ? & & 4 & S.F. & $\ldots$ \\
\hline II. & 5 & $\left\{\begin{array}{r}1+1 \\
+2\end{array}\right.$ & 3 & $\ldots$ & & $\begin{array}{l}\cdots \\
\ldots\end{array}$ & S.F. & $\ldots$ \\
\hline I 2. & $5 ?$ & $\mathrm{I}+3$ & $2 ?$ & 2 & & $\ldots$ & $\ldots$ & $\begin{array}{l}\cdots \\
\cdots\end{array}$ \\
\hline I3. & 4 & $\left\{\begin{array}{r}I+1 \\
+2\end{array}\right.$ & $2+I$ & $?$ & & $\ldots$ & M.F. small & ... \\
\hline I4. & 5 & $I+3$ & 3 or 4 & $\dddot{\dddot{2}}$ & & $\begin{array}{l}\cdots \\
\cdots\end{array}$ & M.F. small & $\dddot{e}$ \\
\hline $15 .^{*}$ & 4 & 4 & 4 & 2 & & $\ldots$ & M.F. & $f$ \\
\hline 16.* & 4 & $4 ?$ & $4 ?$ & 2 & & $\ldots$ & S.F.? & $\ldots$ \\
\hline I 7. & 5 & $I+3$ s.p. & 4 & 3 & & $\ldots$ & M.F. & $\cdots$ \\
\hline 18. & 5 & $I+3$ & 4 & $\ldots$ & . & $\ldots$ & a.i., s.e. & $\ldots$ \\
\hline 19. & 5 & $I+3$ & 4 & 2 & & $\ldots$ & a.i., s.e. & $\ldots$ \\
\hline 20. & 5 & $1+3$ & 4 & 2 & & $\ldots$ & a.i., s.e. & $\ldots$ \\
\hline 21. & 5 & $I+3$ & $3+I$ & 2 & & $\ldots$ & I a.e., 3 a.i., s.e. & $\ldots$ \\
\hline 22. & 5 & $I+3$ & 4 & 2 & & ... & a.i., s.e., M.F. & d \\
\hline 23. & 5 & $I+3$ & 4 & 2 & & $\ldots$ & a.i., s.e., M.F. & $d$ \\
\hline 24. & & $\ldots$ & $\cdots$ & $\ldots$ & & $\cdots$ & $\begin{array}{l}\text { Opening flower un- } \\
\text { developed A. and G. }\end{array}$ & $\ldots$ \\
\hline 25. & 5 & $I+3$ & $3+I$ & 2 & & $\cdots$ & I a.e., 3 a.i., s.e. & $\cdots$ \\
\hline 26. & 5 & $I+3$ & 4 & 2 & & .. & $\begin{array}{l}\text { a.i., s.e. anthers M.F. } \\
\text { (shade) (sterile). }\end{array}$ & $c$ \\
\hline 27. & 5 & $1+3$ s.p. & 4 (hairy) & 2 & & $\cdots$ & M.F. a.i., s.e. small & $\cdots$ \\
\hline $\begin{array}{l}28 . \\
29 .\end{array}$ & $\begin{array}{l}\ldots \\
\ldots\end{array}$ & $\cdots$ & .. & 2 & & $\cdots$ & a.1., s.e. similar & $\cdots$ \\
\hline 30. & $\begin{array}{l}\cdots \\
\cdots\end{array}$ & $\begin{array}{l}\cdots \\
\cdots\end{array}$ & & $\cdots$ & & $\cdots$ & M.F. a.i., s.e. & \\
\hline
\end{tabular}

A number of forms (Fig. 4, $a$ ) were also found with short, wide corolla tubes, short filaments, abortive pollen, as far as could be found out from the alcohol material, and styles which were commonly held in the lower lip and had the stigmas dipping into pollen which had possibly dropped from the anthers into the depression in the lower lip. No evidence was found to show whether this self-pollination was effective or not. If all the pollen of the flowers was abortive it could of course have no effect, but if some of it was capable of germination and of pollinating other flowers, there could be no a priori reason against its being effective on the pistil of the flower to which it belonged, for Knuth (23) reports self-pollination as usual in the ordinary flowers of this species.

Similar flowers to these (and certainly not fertile) were formed in the summer in large quantities in plants that were obviously diseased, as they 
were attacked by Perrisea Stachydis. Very few galls, however, were found in the autumn (Connold does not report the occurrence of this gall so far on in the year), and the flowers did not show obvious signs of disease, as did those found in the summer. It is possible that such self-pollinating flowers are due to malnutrition.

Other flowers were also found in which pollination had taken place in the unopened bud. There were comparatively few of these; and it was thought, at first, that the anthers had been accidentally made to dehisce when splitting open the flower. A careful examination of artificially opened flower-buds, however, showed that this was not the case. Bud-pollinated flowers differed from the ordinary buds only in having open anthers and widely divergent stigmas, with pollen on them; such flowers could not be distinguished from the ordinary flower-buds except by opening them.

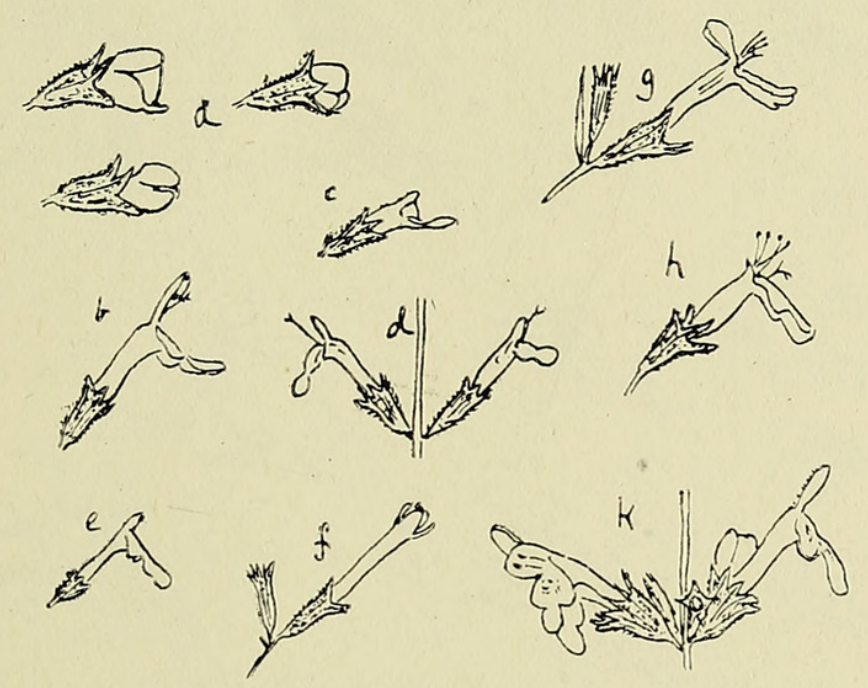

FIG. 4. See Table IV and text. [Bradenham, near High Wycombe, Bucks., I9I9.]

Goebel (17) has figured flowers of Lamium amplexicaule which are similar to the ones here mentioned. I have no evidence to bring forward as to the conditions under which such forms develop. They seemed to be fewer after rain; but few such flowers were found, and I have no information as to the relative frequencies before and after rain.

Near this district, on the chalk, three groups of plants bearing virescent flowers were found (Fig. 5), two groups in a hedge and one just on its borders. All the flowers on these plants were affected; but all other clumps of plants in the immediate neighbourhood, on either side of the hedge, were in every way normal. No sign of any disease, nor of anything that could be related causally to the condition, could be found either in the parts of the plant above ground or in the underground portions. Plants have been gathered and replanted in the hope that further observations might give a clue to the reason for this condition. A note by A. W. Bartlett (3) gives a very careful description of the condition of the gynoecia in two 
abnormal specimens of Stachys sylvatica collected by him, and this description applies also to the plants mentioned above. But my specimens also showed an increase in the size of the calyx, a greening of the slightly reduced corolla, varying from slight strips of green to an almost completely green, and the anthers were affected as well. The flowers were abortive through the phyllody or sepalody of the carpels. The average length of the calyx tube in hedge forms was found to be about $4 \mathrm{~mm}$.; the average length of tube and medium-sized free portion of sepal was about $6.5 \mathrm{~mm}$.; the similar figures for forms growing in woods were $3.5 \mathrm{~mm}$. and $6.7 \mathrm{~mm}$., while the figures for the calyx of virescent forms were $4.6 \mathrm{~mm}$. and $8 \mathrm{~mm}$. The filaments remain short, the anther lobes more or less symmetrical (Fig. 5 b), and the pollen grains are wrinkled and seem destitute of contents. I have

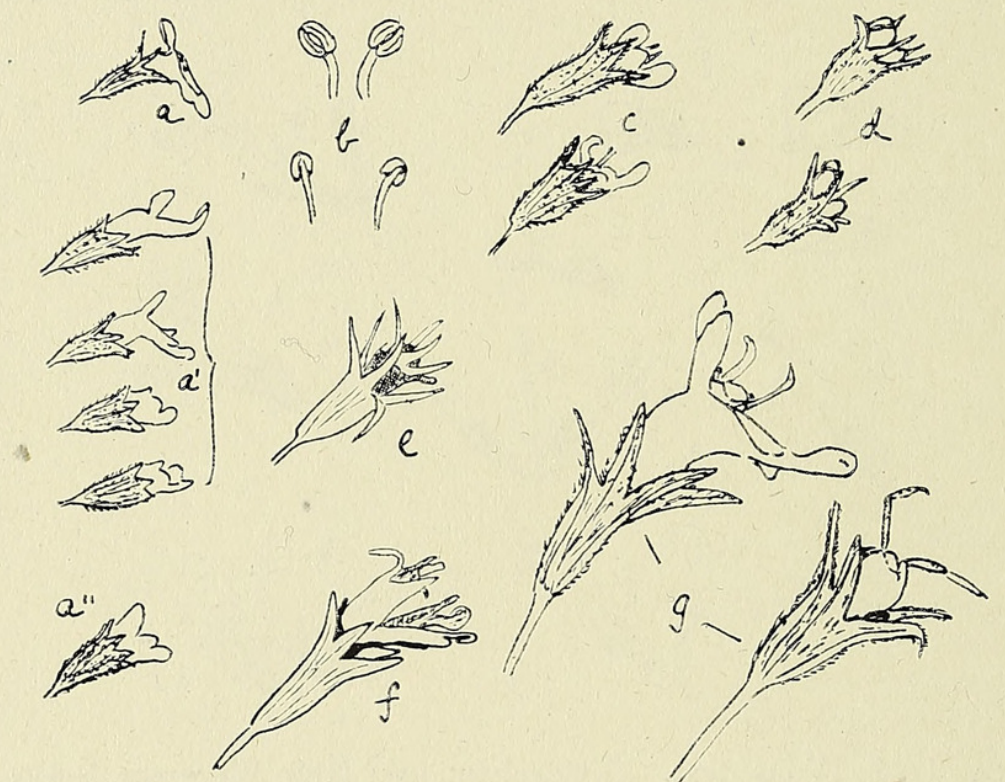

Fig. 5. Virescent flowers from Downley, near High Wycombe, Bucks., I9I9-I920. [See text.] $e, f, g$ slightly enlarged.

very little doubt but that they were abortive. Molliard (26) reports cases of virescence due to animal parasites, and similar cases have been reported by Butler $(7)$ as due to fungal infection, while de Vries (43) has investigated cases in which the tendency to form virescent flowers was inherited, and was intensified under the conditions of his cultural experiment.

In September, 1920, this region was again visited ; virescent plants were found in the same spot, as well as farther along the hedge. The hedge was mostly of hawthorn, but elder plants were fairly abundant. Normal plants were also found growing here. In some of the virescent shoots the four green nutlets had increased in size enormously and showed well above the enlarged calyx (Fig. 5, d), and in other shoots occasional flowers were found in which the ovary had been partially changed into a flower or into two flowers (Fig. 5, $e, f, g$ ), and in the case of other ovaries a flower 
was found to replace the contents of the ovary. Cases were found in which the ovary had been changed into two leaf-like structures, but they were never so much like a leaf as those that Bartlett figures. There seems little doubt that the condition is carried over from year to year vegetatively. The plants here shortly described are probably similar to those mentioned by Townsend in his 'Flora of Hampshire' as var. viridiflora, and regarded by him as abnormal.

\section{TABLE V. Statistical Examination of Open Flowers in the Autumn of 19r9} (near High Wycombe).

Time. Total. Normal. Abnormal. Vs. $\quad$ a.i. C. s. R. F. Y. X.

(a) Blacksmith's Lane: (light period from 4 p.m.)

\begin{tabular}{|c|c|c|c|c|c|c|c|c|c|c|c|}
\hline Sept. I th. & $\begin{array}{l}\text { I } 44 \\
\ldots\end{array}$ & {$[5 \mathrm{I}$ (M.) 77 (S.)] } & $\begin{array}{l}16 \\
\cdots\end{array}$ & & $4 \mathrm{M}$ & $\begin{array}{l}2 \mathrm{M} \\
2 \mathrm{~S}\end{array}$ & $\begin{array}{l}\cdots \\
\cdots\end{array}$ & & $\begin{array}{c}\text { M } \\
\text { (s.p.) }\end{array}$ & & M \\
\hline Sept. igth. & $29^{8}$ & {$\left[\mathrm{I} 06(\mathrm{M} .)^{287}\right.$ I $8 \mathrm{I}$ (S.) $]$} & I I & ; S. & M & $\ldots$ & $\ldots$ & $\ldots$ & $\ldots$ & $2 \mathrm{M}$ & M \\
\hline Sept. 20 th. & 326 & {$[124$ (M.) 165 (S.)] } & $\begin{array}{l}\dddot{3} \\
\ldots\end{array}$ & {$\left[5(\mathrm{M} .)^{14} 9(\mathrm{~S}).\right]$} & $\begin{array}{l}7 \mathrm{M} \\
6 \mathrm{~S}\end{array}$ & $2 \mathrm{M}$ & $\begin{array}{l}M \\
\ldots\end{array}$ & $\begin{array}{l}3 \mathrm{M} \\
2 \mathrm{~S}\end{array}$ & $\begin{array}{l}\cdots \\
\cdots \\
\cdots\end{array}$ & $\cdots$ & $\begin{array}{l}\text { M } \\
\ldots\end{array}$ \\
\hline
\end{tabular}

(b) Blacksmith's Arms Lane: (light period from 11.30 a.m.)
Sept. I 7 th.
$9^{8}$

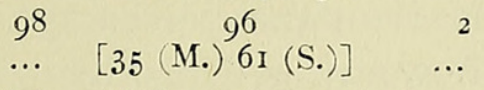
2 (M.)

(c) Plantation Hedge : (light period until about 4.30)

Sept. I6th.

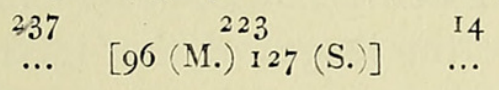

4 (S.)

3 M

$3 \mathrm{~S}$

Plantation Hedge :
Sept. 18 th.
233$$
210
$$
23
$\left[6(\mathrm{M} .)^{18} 12(\mathrm{~S})\right]$

${ }_{\text {I S }}^{\mathrm{M}}$

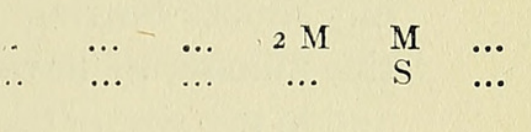

(d) Naphill Chapel Road: (light period from about 4)
Sept. I Sth.

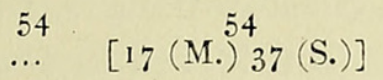

(e) Bungalow Corner: (light period until about 2 p.m.)
Sept. $17^{\text {th. }}$
98
$\cdots$

$$
\left[3^{8}\left(\mathbf{M}^{9}\right)^{8} 60(\mathrm{~S} .)\right]
$$

(f) Cook's Hall Wood:
Sept. I 7 th.
20
[I (M.) 19 (S.)]

(g) Walier's Ash High Road: (light period until about 11.30)

Totals $1,55^{2}$

$\left.\begin{array}{ll}44 & {\left[10(\mathrm{M} .)^{39} 29(\mathrm{~S} .)\right.}\end{array}\right]$

$$
\mathrm{I}, 443
$$

$\begin{array}{lllllll}\text { I S } & \cdots & \cdots & \cdots & \cdots & \cdots & \cdots \\ & & & & & & \\ \ldots & \ldots & \ldots & \ldots & \ldots & \ldots & \cdots \\ \ldots & \ldots & \ldots & \ldots & \ldots & \cdots & \cdots\end{array}$

$\begin{array}{lllllll}\ldots & \ldots & \ldots & \ldots & \ldots & \ldots & \ldots \\ \ldots & \ldots & \ldots & \ldots & \ldots & \ldots & \ldots\end{array}$

$\begin{array}{lllllll}\ldots & \ldots & \ldots & \ldots & \ldots & \ldots & S \\ \ldots & \ldots & \ldots & \ldots & \ldots & \ldots & \ldots\end{array}$

$\begin{array}{ccccccc}\ldots & \ldots & \ldots & \ldots & \ldots & \ldots & \ldots \\ \ldots & \ldots & \ldots & \ldots & \ldots & \ldots & \ldots \\ 32 & 7 & \text { I } & 5 & 3 & 5 & 4\end{array}$

M. = middle flower. S. = side flower. $\quad$ V. = bifurcated upper lips. $\quad$ C. = only slightly opened flowers. $\mathrm{R}_{\mathrm{n}}=$ reduced number of parts. $\mathrm{s}$. = symmetrical flower. $\mathrm{X}$. = unclassified abnormals. $\mathrm{Y} .=$ lower lip of corolla much divided.

It should be mentioned here that a variety of Stachys sylvatica has been found at Shoreham which differs from the type mostly in that there are no markings on the lower lip of the corolla. This plant will be described elsewhere. There is no evidence that any of the plants described here are hybrids. 
After observing bud-pollination and the forms with abortive and reduced stamens, it was determined to obtain information regarding the frequency and distribution of the respective variants. Several places were selected, in the same neighbourhood, where the Stachys was growing in quantities and the number of normal and abnormal open flowers were noted, in every case examining the flowering shoot from below upwards and distinguishing between the middle and side flowers of the side dichasia. The areas selected were typical ones, mostly hedgerows, and differed especially in the direction they faced, and therefore in the length of their daily exposure to sunshine. In the two sites provided with the greatest illumination $(e$ and $c)$ there were practically no variants but those with forked upper lips; and in another area $(b)$, where the lighting was very good and the hedge plants had recently been cut (a few days before counting, no open flowers were present, and a week before no signs of inflorescences could be seen), only two variants were found. The wood records are not typical, as there were few flowers remaining in such shady situations. The percentage of middle flowers with stamens having short filaments will be found to be much smaller than the percentage of side flowers in a similar condition. This result, however, is deceptive. Flowering shoots bearing such flowers were very much reduced, not so much in the number of flowers borne as in regard to the length of the 'internodes' and in the size of the flower; most of the corollas never opened, but withered in situ, and the greater number of them did not develop their nutlets to maturity. In fact no information was obtained as to whether the fruits of such flowers ever matured. The majority of such side flowers, therefore, probably never open, and their condition was not considered in the above numerical statement, nor was the frequency of bud-pollination recorded.

In June-July, 1920, plants were again examined on the chalk in Kent. Fusions and symmetrical flowers were commonly found, and a few flowers with reduced parts, i. e. two lobes to lower lip of corolla or with three similar lobes to lower lip of corolla. These latter cases were always the last-opened flowers on side verticillasters which were usually in a low position on the plant, and their condition can be taken to be due to deficient nutrition. In all the very numerous cases in which the corolla tube was wide open and the stigmas were bent over and fitting into the lower lip of the corolla, there were undoubted signs of disease, and the 'grub' itself was seen low down in the corolla tube in nearly every case. The fusions were difficult to treat statistically, for in some clumps of the plant there would be no abnormals of any kind, in other regions there would be a few of various sorts including a fusion, and in other places again there were plants showing a large number of these negative dédoublements and, as far as could be discovered, little else that was abnormal. Counts were made in one such patch; all the plants were affected and nearly all were examined statistically, 
those counted being taken at random. Comparatively few open flowers showed fusions, and in the counts all signs of fusing, whether in bud, flower, or fruit, were made note of (the half-verticillasters were counted and not individual flowers.)

$\begin{array}{cccccccc}\text { Plants. } & \text { Total half- } & \text { Normal half- } & \text { Fusions. } & \begin{array}{c}\text { Normal middle } \\ \text { verticillasters. }\end{array} & \text { Fusions. } & \text { N. side. } & \text { Fusions. } \\ \text { verticillasters. } & \text { verticis } & \text { Fus } & 90 & 162 & 87 & 168 & 4\end{array}$

It will be found that most of the fusions were in the middle half-verticillasters, and but few on the side compound inflorescences; nearly all the fusions were between two flowers, but three were between three flowers. The only thing noticeable that was remarkable in the position of these plants was that they had formerly been overshadowed by a row of elm-trees growing on the opposite side of the road. The trees had been removed recently (in December, 1919).

The symmetrical flowers are found much more rarely, but in all kinds of situations, and in hedgerows facing in any direction. They are in every case apical flowers of side compound inflorescences.

The smaller Stachys shoots bear a series of opposite pairs of half-verticillasters arranged in a racemose manner; larger shoots, in the pair of leaves just below this simple construction, will be provided with a similar pair of racemosely arranged verticillasters, and in plants that are even more strongly developed there may be several such structures.

In fairly well developed plants, with the simplest construction, the flowers on the lowest verticillaster will be longer stalked than usual, and in the cases of symmetrically constructed flowers, that I have already described, it has been noted that the half-verticillasters bearing them are a little more complicated than usual and approximate to trichasia.

In the symmetrical forms examined this summer it seemed clear that a series of transitions could be found between the simpler form of dichasium through the trichasium to the cases where, in a similar position, were to be found a series of verticillasters arranged in a spike-like manner. It is in these transitional forms of inflorescence that symmetrical flowers are to be found; such flowers are older than the flowers immediately below them, and in many, if not in all, of the plants examined by me stand in the relation of first or older dichasial flower to the flower above it, i.e. next the main upright shoot-and also to the one below it, i.e. on the side away from the main upright shoot.

This apical flower often partially fuses with one of the side flowers of this dichasium, and then, although it can be seen that the plan of the flower was on a symmetrical pattern, the fused structure is contorted to one side and it is very difficult, if not impossible, to distinguish the parts, the corolla tube sometimes being open and fused with the calyx cap, which is also split. It seems likely, then, that the symmetry is brought about when the lowest 
inflorescence is passing through a series from the compound spike to the simple dichasium, and at the particular point when either a trichasium is found or when there is a top flower to a fairly complex inflorescence bearing side flowers in a dorsal and ventral position.

I can offer no opinion as to the external conditions which control the formation of these transitional forms of inflorescence.

In one case an almost symmetrical side flower was found, but even here it was a part of a trichasial system.

It will be remembered that Peyritsch (31), in his various papers on the cause of peloria, was of the opinion that in several Labiatae sudden changes in illumination induced this condition, and that he brought forward a certain amount of experimental evidence pointing in this direction. I have found peloric flowers in Galeobdolon luteum, the plant experimented on by Peyritsch, in a hedgerow which had been greatly depleted of its shade.

Last year (1920) plants collected in the neighbourhood of Radlett, Herts., were planted in my gardens, some in the shade (under a tree) and others in a more open situation. As would have been expected, the shade plants flowered (i. e. bore open flowers) later than the sun ones, indeed about a week after-those in the sun flowering on May 24, and those in the shade on June 1 . The general condition of the shade flowers was unsatisfactory; they often withered before they opened; they were stunted, and, so far, one case of fusion has been observed amongst them. On a shoot, on which but few flowers were open and those towards the light, a flower was found with a bifurcated upper lip.

The sun plants seemed, on the whole, normal, but one plant bore two flowers with lower lips having the middle lobe like the side ones (with two lobes instead of three to the lower lip). One of these flowers was a late developed one in the lowest verticillaster, and the other was found on the third verticillaster in a similar position.

\section{- Discussion.}

There are a large number of observations showing that external conditions (time of year, good or bad nourishment) and the position, advantageous or otherwise, of the inflorescence on the plant have an effect on the number of flowers in a capitulum in the case of the Compositae (35) and on the number of members in the whorls of individual flowers in many other cases. MacLeod (25) found, for example, that in some plants of Ramunculus ficaria the percentage of members in a whorl was smaller under adverse circumstances. Correns $(8,9)$ obtained similar results in Satureia hortensis ; Burkill (6) reports that in Bocconia and many other plants examined statistically by him the flowers in favoured positions on the inflorescence had a larger number of sporophylls, and Salisbury (33) recently notes that this is the usual, though not the invariable, state of affairs in the case of the 
carpels of Clematis Vitalba Goebel (18) mentions that in the Caryophyllaceae the first flowers to open are often hexamerous, while the later ones are pentamerous, and that in Ruta graveolens the terminal flowers of the cyme are pentamerous, the others tetramerous. A survey of similar cases can be found in Vernon's 'Variations in Animals and Plants' (40) and in de Vries's 'Mutation Theory' (43). The position of the flower together with a reduced number of parts in Stachys sylvatica suggest that bad nutrition is the causal factor, and it is probable that some cases of increased numbers of parts are due to increased nutrition, though some of these cases are probably the results of fusions between two or more flowers, and an explanation must be sought for these by considering the causes of fusions in Stachys flowers.

The cases where five stamens develop, instead of the usual four, cannot be regarded as infringements on the 'law of loss' recently put forward by Dr. Agnes Arber (1), for in the allied Stachys recta Payer (29) described five rudiments of stamens, four of which develop. In the cases mentioned above it is possible that the posterior rudiment develops instead of aborting.

The decrease in number of members in the corolla seems to take place independently of the time of year. An increased number of petals seems commoner in summer, and the change in the number of members in the androecial whorl, if not accompanied by any change in any other part of the flower, seems to be more dependent on the time of year than on the position of the flower in the inflorescence.

As regards the fused flowers, it is difficult to assign any particular reason for the phenomenon. Worsdell (49) truly says that it is not surprising that such an occurrence is common amongst the Labiatae because the flowers are so very near to each other. The actual number of flowers is not of much importance, for in such species as Ballota nigra, where the number of flowers in a dichasium is very much greater than in Stachys sylvatica, fusions are rare-partly, no doubt, owing to the longer flower peduncles-and in Stachys itself the fusions do not seem to be found in greater numbers in portions of the plant where most flowers are found in a verticillaster ; and not only so, but where a fusion is found there is sometimes no fusion in the opposite half-verticillaster, even if the latter contains more flowers than the former. The fusion, indeed, seems to be mostly conditioned by the non-development of the flower peduncle. Some check to its formation must happen just before the floral organs are about to be laid down. It has been noticed that in depauperate forms not only are the numbers in a whorl smaller than in the normal species, but that they are often fused. In very small scapes of Ophrys apifera I have found small flowers without the two posterior petals and with the posterior sepal fused with one of the side sepals, and similar cases have often been described elsewhere. Also in Fraximus excelsior vegetative buds, that would otherwise only develop next spring, if at all, often open, in late summer or the 
beginning of autumn, as a consequence of injury to the apical bud; in such cases, structures that would ordinarily be developed as scale leaves are formed into transitional leaves. Such structures, if situated in the anteriorposterior plane, have enlarged bases which are quite free; if, however, they are placed right and left of the shoot, the bases are generally fused on the side towards the parent shoot, but free on the other side. It is possible that some comparable nutritional disturbance is responsible both for the fusion between flowers in Stachys, and for the occasional bifurcation of the upper lip of the corolla.

The tendencies to bud-pollination and gynomonoecism were shown only in the autumn. The work of Vöchting $(41,42)$ has indicated that in Mimulus light is the controlling factor in cleistogamy, and in other plants temperature also has been shown to be important; while Graebner, in I 893 (19), has expressed the opinion that cleistogamy is brought about by any adverse influence, e.g. lowering of temperature, amount of light, or the weakening action of fungi. Willis (45-48) is in agreement with this view, and also expresses the opinion that the peculiar distributions of the sexes seen in the Labiatae and other orders are also expressions of the action of external adverse conditions. It is not known precisely what set of external conditions favour cleistogamy rather than gynodioecism or androdioecism. It is possible that the time of action of the factor relative to the stage of development of the plant or flower must be taken into consideration. The observations of Delassus $(11,12)$ and of Urbain (39) are here of some importance, for they have shown that the effects of partial or complete removal of the endosperm or of fleshy cotyledons are felt far into the life of the plant, influencing the time of flowering, the number of flowers, and in some plants producing frequent sexual abnormalities. This fact makes the investigation of any such phenomena difficult, for it is not an easy matter to trace back any anomaly to its cause, and the case of Stachys would be especially difficult as, when in bloom, it has many flowers in different stages, and these flowers react on one another, the development of one flower often causing the non-development of another by correlation.

Klebs's work on the importance of light in bringing about flower formation (22), ${ }^{1}$ and especially the extension of this view by which it is held that an excess of starch-formation is responsible for flowering and an excess of salts for vegetative development, impresses on us the presence of quantitative factors as apart from qualitative ones. Sprecher's results on Rumex and Cannabis (36), in which genera he finds that in the different sexes there are different osmotic pressures in the expressed juices and that the mineral and organic matters present in the extract are also not the same, point to conclusions similar to those to be drawn from Klebs's work. It is true that several workers have held that the sex in hemp and similar plants is fixed

\footnotetext{
1 See also Garner and Allard (14), and Giron de Bazareingues (16).
} 
from the seed and that nutrition has no effect in altering it. Haberlandt (20), Heyer (21), and Fisch (13), have expressed this opinion for this particular plant. Other workers, however, have shown that mutilation and changed conditions can bring about a change of sex in hemp (Pritchard (32), Schaffner (34), Tournois (38)). Similar observations have recently been recorded for Myrica Gale (Davey and Gibson (10)) and for Plantago lanceolata (Stout (37), Bartlett (4,5), Ludwig (24)); while Yampolsky has not only given us the results of his own work on Mercurialis annua, but has provided us with a summary and review of previous work on so-called intersexes $(50,51,52){ }^{1}$

The fact that Stachys plants, in the autumn, bear a certain number of female flowers makes an addition to the number of plants in which it has been shown that the development of 'sporophytic' sex is dependent on external conditions.

\section{SumMaRY.}

I. During the months of June, July, August, September, and October, plants of Stachys sylvatica have been observed, showing peloria, semi- peloria, fasciations, synanthy, chloranthy, increase and reduction in number of parts of all four whorls, a tendency to abortion of the stamens (gynomonoecism), and 'bud-pollination'.

2. The semi-peloric flowers were apical flowers on the more important side inflorescences, and their position on the plant was rendered more symmetrical, either by injury to the main stem or by the development of a trichasium through the formation of flowers between the peloric flower and the main axis.

3. An increase in the number of members in a whorl must probably be connected with increased nutrition, and a reduced number with conditions inimical to good nutrition.

4. The abortion of stamens is accompanied by a marked decrease in size of calyx and corolla, the smaller side flowers withering without opening. Such flowers were found mostly in the autumn.

5. The variants noticed in the autumn were fewer in warm and sunny situations and were mostly of the nature of a bifurcation in the upper lip of the corolla. In two regions practically no departures from the normal were noticed; and in the case of one of these regions, which was well lit, the flowers were all borne on new shoots and were, therefore, probably making use of the food stores of the underground rhizomes.

6. Early in the year the tendencies exhibited are towards an increase in the number of parts, especially in the androecium and gynoecium, and an exhibition of fasciations. Such features are usually shown in the middle flowers. During the whole of the year notched upper corolla lips were

$$
1 \text { See also Giard (15) and Wester (44). }
$$


common, but no statement can be made regarding their relative frequency. Fusions between a middle and a side flower were more commonly found and are difficult to distinguish from fasciations.

Flowers with a reduced number of parts in the corolla are common all the year, and these are found to be side flowers. In September a tendency to gynomonoecism and possibly to self-pollination is shown, and 'bud-pollinations' occur. It is not known whether self-pollination, under these circumstances, is effective or not.

\section{BIBLIOGRAPHY.}

1. Arber, Agnes (1919): On Atavism and the Law of Irreversibility. Am. Journ. Sci., 4th Series, xlviii.

2. Arber, E. A. N.: On the Synanthy in the Genus Lonicera. Journ. Linn. Soc., Bot., xxxv. $4^{63}$.

3. Bartlett, A. W. (1909): On an Abnormal Gynodioecism in Stachys sylvatica, Linn. New Phyt., viii. $3^{8 .}$

4. Bartlett, H. H. (1911): On Gynodioecism in Plantago lanceolata. Rhodora, xiii. 199-206.

5. (1913): Inheritance of Sex Forms in Plantago lanceolata. Ibid, xv. I $73-8$.

6. Burkill, J. H. (1895) : On some Variations in the Number of Stamens and Carpels. Journ. Linn. Soc., xxxi. 2 I6.

7. Butler, E. J. (1918) : Fungi and Diseases in Plants. Calcutta.

8. Correns, C. (1906): Die Vererbung der Geschlechtsformen bei den gynodioecischen Pflanzen. Ber. . deutsch. Bot. Gesell., xxiv. 459-74.

9. $(1907)$ : Zur Kenntniss der Geschlechtsformen polygamer Blüthenpflanzen und ihrer Beeinflussbarkeit. Jahrb. wiss. Bot., xliv. 124-73.

10. Davey, A. J., and Gibson, C. M. (1917): Note on the Distribution of the Sexes in Myrica Gale. New Phyt., xvi. 147-5I.

11. Delassus, E. (1911): Influence de la suppression partielle des réserves de la graine sur le développement de la plante. C. R. de l'Acad. des Sc., Paris, cliii. I494.

12. $(1912)$ : Influence de la suppression partielle des réserves de la graine sur l'anatomie des plantes. Ibid., clvii. 228.

13. Fisch, C. (1887) : Ueber die Zahlenverhältnisse des Geschlechtes beim Hanf. Ber. d. deutsch. Bot. Gesell., v. I36-46.

14. Garner, W. W., and Allard, H. A. (1920): Effect of the Relative Length of Day and Night and Other Factors of the Environment on Growth and Reproduction in Plants. Journ. Agri. Research, xviii, No. II.

15. Giard, A. (1889): Sur la transformation de Pulicaria dysenterica Gaertn. en une plante dioïque. Bull. Scient. Français et Belge, xx. 53.

16. Giron de Bazareingues, $\mathrm{CH}$. (1831): Suites des expériences sur la génération des plantes. Ann. Sci. Nat., Bot., xxiv. I38-47.

17. Goebel, K. (1908) : Einteilung in der experimentellen Morphologie der Pflanzen. Leipzig : B. G. Teubner.

18. (1905): Organography of Plants, vols. i and ii. (English Trans.) Oxford.

19. Graebner, P. (1893): Biologische Notizen. Verh. Bot. Ver. Brandenburg, xxxv. I 48.

20. Halierlandt, Fr. (1869): Wiener landwirt. Zeit.

21. Heyer, Fr. (1884): Untersuchungen über das Verhältnis des Geschlechtes bei einhäusigen u. zweihäusigen Pflanzen. Ber. aus d. physical. Lab. d. landwirt. Inst. d. Univ. Halle. 
22. KI.EBS, G. (1905-1906) : Über Variationen der Blïten. Jahrb. f. wiss. Bot., xlii.

23. Knuth, P. (1909): Handbook of Flower Pollination, vol. iii. (English Trans.) Oxford : Clarendon Press.

24. Ludwig, F. (I880) : Über die Blïtenformen von Plantago lanceolata, L., und die Erscheinung der Gynodiöcie. Bot. Centralbl., i. $33 \mathrm{I}-3$.

25. MACLeOD, J. (1897): Botanisch Jaarboek, xi.

26. Molliard, M. (1900): Cas de virescence et de fasciation d'origine parasitaire. Rev. Gén. de Botanique, xii.

27. Moore, David (1870): On the Morphology of Sexes in some Dioecious Plants. Trans. Royal Irish Acad., xxiv, Science.

28. Muth, F. (1906): Über die Verwachsungen der Seitentriebe mit der Abstammungsachse bei Salvia pratensis, L., sowie über einige andere teratologische Erscheinungen an derselben. Ber. d. deutsch. Bot. Gesell., Nr. 353, Bd. xxiv.

29. Payer (1857): Traité d'organogénie de la fleur. Paris.

30. Penzig (1894) : Pflanzen-Teratologie, Bd. ii. Genua.

31. Peyritsch, J. (1877): Untersuch. über die Aetiologie pelorischer Blïtenbildungen. Denkschriften der Wiener Akad. d. Wissensch., xxxviii, pt. ii.

32. Pritchard, F. J. (1906): Change of Sex in Hemp. Journ. of Heredity, July.

33. Salisbury, E. J. (1920): Variation in Anemone Apennina, L., and Clematis Vitalba, L., with Special Reference to Trimery and Abortion. Ann. Bot., xxxiv.

34. Schaffner, J. H. (1919): Complete Reversal of Sex in Hemp. Science, ii. 50.

35. Shull, G. H. (1902): A Quantitative Study of Variation in the Bracts, Rays, and Disk Florets of Aster Shortii, Hook, A. Novae Angliae, L., A. Puniceus, L., and A. Prenanthoides, Muhl., from Yellow Springs, Ohio. Am. Nat., xxxvi. I I I.

36. Sprecher, A. (1913): Recherches sur la variabilité des sexes chez Cannabis sativa, L. et Rumex acetosa, L. Ann. Sci. Nat., Bot., $9^{\mathrm{e}}$ série, xvii. 255-352.

37. Stout, A. B. (1919): Intersexes in Plantago lanceolata. Bot. Gaz., lxviii.

38. Tournois, J. (1914): Études sur la sexualité du Houblon. Ann. Sci. Nat., Bot., $9^{\mathrm{e}}$ série, xix. 49-I9I.

39. Urbain, J. A. (1913): Modifications morphologiques et anormales florales consécutives à la suppression de l'albumen chez quelques plantes. C. R. de l'Acad. des Sc., Paris, clvii. 450.

40. Vernon, H. M. (1903): Variation in Animals and Plants. Inter. Sci. Series.

41. Vöchtung, H. (1893): Ueber den Einfluss des Lichtes auf die Gestaltung und Anlage der Bliithen. Jahrb. fiir wiss. Bot., xxv.

42. (1898): Ueber Bliithenanomalien. Ibid., xxx.

43. DE VRIEs, H.: The Mutation Theory. (English Trans.) London: Kegan Paul, Trench, Triibner \& Co., Ltd.

44. Wester, P. J. (1914): The Determination of Sex. Journ. of Heredity, v. 207-8.

45. Willis, J. C. (1892): Gyrodioecism in the Labiatae. Proc. Camb. Phil. Soc., vol. vii, pt. 6, p. 349 .

46. (1892): Gynodioecism in the Labiatae. Ibid., vol. viii, pt. I, p. I7.

47. - (1893-1894): On Gynodioecism, with a Preliminary Note upon the Origin of this and Similar Phenomena. Ibid., pt. 3, p. I29.

48. + (1894): The Natural History of the Flower. Nat. Sci., vol. iv, No. 27 .

49. Worsdell, W. C. (1916): Principles of Plant Teratology, vol. ii. The Ray Society.

50. Yampolsky, C. (1916): Observations on Inheritance of Sex Ratios in Mercurialis anmua. Mem. N.Y. Bot. Gard., lxv. 69-74.

51. (1919): Inheritance of Sex in Mercurialis anmua. Am. Journ. Bot., vi. 4Io-42.

52. (1920): The Occurrence and Inheritance of Sex Integration in Plants. Ibid., vii. 


\section{$2 \mathrm{BHL}$ Biodiversity Heritage Library}

Cutting, E. M. 1921. "Observations on variations in the flowers of Stachys sylvatica, Linn." Annals of botany 35, 409-425.

https://doi.org/10.1093/oxfordjournals.aob.a089765.

View This Item Online: https://www.biodiversitylibrary.org/item/235780

DOI: https://doi.org/10.1093/oxfordjournals.aob.a089765

Permalink: https://www.biodiversitylibrary.org/partpdf/319010

\section{Holding Institution}

Smithsonian Libraries

\section{Sponsored by}

Biodiversity Heritage Library

\section{Copyright \& Reuse}

Copyright Status: Not in copyright. The BHL knows of no copyright restrictions on this item.

This document was created from content at the Biodiversity Heritage Library, the world's largest open access digital library for biodiversity literature and archives. Visit BHL at https://www.biodiversitylibrary.org. 